\title{
Differences in political participation between young and old people
}

\author{
ELLEN QUINTELIER \\ Catholic University of Leuven, Belgium
}

People often complain about the supposed laziness and ineptitude of the younger generation, remonstrating their lack of respect for the traditions and seniority of the older population. These reactions are not new, however, as Plato voiced similar concerns about the young people of his time:

The children now love luxury; they have bad manners, contempt for authority; they show disrespect for elders and love chatter in place of exercise. Children are now tyrants, not the servants of their households. They no longer rise when elders enter the room. They contradict their parents, chatter before company, gobble up dainties at the table, cross their legs, and tyrannize their teachers. ${ }^{1}$

We also find a similar reaction among political researchers, whenever they conclude that young people are not sufficiently engaged in politics. ${ }^{2}$ Such a conclusion is not unfounded: in almost every election young people are the least likely to vote, and these participation rates are continuously declining; ${ }^{3}$ the youth membership of political parties is dropping; ${ }^{4}$ young people are less concerned with politics, less politically knowledgeable, do not participate in social or political activities, are more apathetic, and have low levels of political interest, etc. ${ }^{5}$ For almost every activity or attitude, young people have the lowest score. Conventional 'wisdom' dictates that young people are 'ignorant', 'apathetic', 'selfish', 'indifferent', 'alienated', 'disaffected' and 'disinterested' when it comes to politics. ${ }^{6}$ Negative media discourses also add to these views. ${ }^{7}$ Others argue that young people cannot participate politically until they become eligible voters. ${ }^{8}$ Either way, it appears that young people and political participation present an unlikely and perhaps incompatible combination.

But are young people doing such a bad job? Do they really have such low levels of involvement? In the literature, we find three reasons for these images and the perceived political participation gap between younger and older people. Firstly, due to the lifecycle and generational effects, young people have fewer reasons to participate: they do not have a house, stable residence, children ... factors which make people more likely to engage in political participation. Secondly, the attractiveness of new forms of participation has caused younger people to divert from traditional forms of political participation as practised by the older generation, like voting or political party membership. Rather, young people prefer 
local community actions, political consumerism, new social movements and activities, single-issue politics, protest politics, etc. Thirdly, there is a perceived difference in the political attitudes of young people: it is often stated that young people have less interest in politics, more negative attitudes, and also less trust in the political process. There are already many theoretical papers and books on this subject; however, there is a lack of solid, empirical testing. Firstly, I describe these three arguments and then develop and test three hypotheses to gather evidence for the theory.

\section{Lifecycle and generational effects}

The first reason for young people's lower levels of political participation (compared to older respondents) is the lifecycle. ${ }^{9}$ One of the effects of lifecycle is that as young people become older they get more experienced in the electoral and political process. ${ }^{10}$ The reason for this effect is that young people lack the resources that older people have accumulated through life, as each group occupies a different social role. Most of these differences will disappear, however, as young people grow older, their levels of education increase, their place of residence stabilizes and integration into the community increases. ${ }^{11} \mathrm{Gen}$ erally, 18 year olds do not hold university degrees. Young people also experience technical 'start-up' problems in political participation: they are more likely to be recently moved and consequently are less likely to vote as their social ties are often disrupted; in some countries, they face the added burden of re-registering. ${ }^{12}$ Being married and having a permanent job, factors that are less common among young people, also have a positive influence on voter turnout. ${ }^{13}$ Finally, and as can be expected, young people also have fewer social and political ties. But as one can logically assume, these things are very rare among young people.

Each life stage also has its own distinct characteristics and social inclinations: for example, while young people are likely to be members of youth groups or sports teams, the middle-aged are more commonly members of parent-teacher associations, and the retired will generally be members of groups that are geared to senior citizens. ${ }^{14}$ Moreover, some forms of political participation are not possible for young people due to age restrictions, the most significant of which is voting. ${ }^{15}$ It can be argued that young people, as ineligible voters, are 'non-citizens' or 'apprentice-citizens' ${ }^{16}$ According to Parry et al. ${ }^{17}$ this is a very important issue because for $50 \%$ of adults the act of voting constitutes the only form of political participation. Without the right to vote, young people miss out on the biggest stepping stone to increased political action, and, not surprisingly, will have lower levels of political participation. Bessant ${ }^{18}$ notices some other restrictions, namely in the patronizing of youth by parents and educators. This is displayed in that politicians, parents and teachers frequently deny their children or students the right to participate in protest marches when such activities take place during class hours. Nonetheless, there are still some who argue that, except for voting, young people and adults have equal opportunities for political participation. ${ }^{19}$

Hence, though age is a good predictor of political participation, young people have little control over its impact because of the particular generational effects they are necessarily subjected to. These effects influence when and how people become politically aware. ${ }^{20}$ Moreover, generational effects are associated with 
'general' or 'idealistic' views. ${ }^{21}$ However, there is also some indication that the more recent generations are even less likely to engage in political participation than were previous generations of the same age. ${ }^{22}$ The generational effects suggest that today's young people are less active, and that they will never reach the levels of political participation currently displayed by the elderly. ${ }^{23}$ One explanation suggests that young people now face more difficulties in the transition to adulthood, and that this longer transition period leads to an inevitable delay in political participation. ${ }^{24}$ Studies indicate that such younger generations will retain these differences as they grow older, and that consequently the present electorate will be replaced by a more passive generation of political participants. In the following analyses we will test whether young people are less politically active than older people, and, for positive results, whether the differences in political activity can be explained by lifecycle effects. Our first hypothesis is, therefore, that differences between young and old, in terms of electoral behaviour and political participation, can be attributed mainly to lifecycle effects.

\section{Preference for new and other forms of political participation}

A second problem is the interpretation of the results of political participation surveys. In most quantitative studies, when researchers find that young people participate at lower levels they conclude that they are indifferent to politics. But this should not necessarily be the case as, according to O'Toole et al., young people can engage in other forms of political participation which are not often surveyed by researchers. ${ }^{25} \mathrm{O}^{\prime}$ Toole et al. state that:

The most significant factor in young people's non-participation, some of whom are politically motivated and engaged, although in ways that orthodox research does not explore. ${ }^{26}$

It may be that young people find it more difficult to fit traditional forms of participation into their lifestyles and jobs, ${ }^{27}$ or that conventional politics carries an image problem for young people. ${ }^{28}$ This could be why young people are disproportionately attracted to new (informal) forms of political action, or 'cause-oriented' styles of politics. ${ }^{29}$ While these new forms of political participation are sometimes regarded as less 'political' in nature, they may serve as stepping stones to more traditional forms of political participation. ${ }^{30}$ In light of the increase in new forms of participation, however, extra caution must now be taken when discerning between political and non-political forms of participation.

Some authors argue that certain types of participation are increasing more than others, such as: youth councils and parliaments, youth hearings, local community actions and campaigns, political consumerism, disruption, use of slogans, renaming of familiar objects, new social movements, single-issue politics, protest politics and peer support groups. ${ }^{31}$ These forms of political participation are more informal than voting, for instance, or being a member of a political party, and are particularly more attractive to young people. ${ }^{32}$ Typical examples include, signing petitions, donating money, forming campaign groups and demonstrating. Henn et al. ${ }^{33}$ argue that if young people were able to discuss political participation in their own terms (with the widening of the definition to include more forms of political participation), political scientists would find greater evidence for an active young electorate and, more generally, higher levels of total political 
participation. ${ }^{34}$ This argument rests on the idea that some of the activities that young people do not classify as political phenomena can indeed be considered political in nature. ${ }^{35}$ In our analyses we will investigate whether young people really do prefer other forms of political participation than those practised by older people.

So, if we focus not only on traditional participation but also on newer forms of participation, we might be able to conclude that although some of the newer forms are less 'political', they are still valuable indicators for measuring young people's political participation. In the empirical part of our research, we will investigate in depth whether young people actually do prefer forms of participation that differ from the traditional political activities observed by the older generation. Our second hypothesis is, therefore, that young people prefer other forms of political participation than those commonly practised by older people.

\section{A different conception and different attitudes towards politics}

The difference in perspective presents a third problem, as young people generally embrace a narrower conception of politics or political participation than do researchers. ${ }^{36}$ Avoiding such definitional discrepancies is very important in social research: it is not only important for a researcher to have a good definition of the investigated topic but also for that definition to be used and accepted by the survey population. In our case, we should be careful that the acts we consider political are likewise considered political by our younger audience. As Hay ${ }^{37}$ comprehensively demonstrates, there are different definitions of 'politics'. According to Parry et al., ${ }^{38}$ however, there is a huge discrepancy between the definition of politics espoused by researchers and by the people: only $18 \%$ of the respondents interpreted the list of activities composed by the researchers as political. Wittebrood discovered a similar discrepancy when noting that Dutch youth view politics as something that happens in 'The Hague' (where the Dutch parliament is located), while researchers mainly use a broader definition of 'politics'. ${ }^{39}$ Similarly, Henn et al. ${ }^{40}$ found that the two most popular answers to the question 'what is politics?' were also based on this narrow conception of politics. Firstly, 'the government', given by $25 \%$ of respondents, and secondly, 'how the country is run', given by $19 \%$ of respondents. Other authors ${ }^{41}$ suggest that it is necessary to use an even broader definition of the 'political', because such a definition would lead to higher noted levels of political engagement.

This factor will later help to explain why young people are not as interested in politics as are older people: young people do not view politics (in their very small conception) as relevant to their daily lives. ${ }^{42}$ This is also why some have suggested avoiding closed questions when asking about political participation because they assume a shared understanding between researcher and respondent where there may be none. ${ }^{43}$ So when surveying political participation, researchers should be careful to examine forms of participation which young people might regard as political. ${ }^{44}$ There is also some speculation that the lower political participation rates may be partly explained by the fact that younger people have not yet developed mental categories for sorting activities, ${ }^{45}$ and thus are more likely to answer that they do not do an activity, even while they are doing it. This should encourage researchers to use examples of organizations and activities in their questionnaires. Though this might lead to an overrepresentation of the mentioned organizations 
or activities, it will yield a more accurate and realistic answer. Generally, we expect to find lower levels of political participation among the younger population than among the older population when we use more traditional questions.

Young people also see politics as irrelevant in their lives. ${ }^{46}$ This is partly justifiable because generally they will not yet have bought a house, they are usually unemployed, and are mostly disconnected from a political world dominated by adults. Young people do not yet have a stable basis for concern with politics and are more preoccupied with short-term projects. ${ }^{47}$ Conversely, the low political participation rate among youth is a by-product of their narrow conception of politics and their impression that politicians do not truly care about their needs. Young people are very critical and quickly recognize when politicians are 'faking' or when they wrongly try to speak on their behalf. ${ }^{48}$ Some critics also say that politicians too often assume that young people are not qualified to engage in decision making because of their 'deficient cognitive, social, and ethical abilities $^{49}$ and that consequently they are rarely heard as expert citizens even though they may be politically involved. ${ }^{50}$ Henn et al. ${ }^{51}$ found that the nonparticipation of young people is due to the failure of politicians to address the issues that concern young people, or to make the issues relevant to their lives. Moreover, young people perceive politicians as 'out of touch', untrustworthy, self-interested, irrelevant and power hungry, more than older respondents do. ${ }^{52}$ Many young people feel that they are not heard by politicians and that they ultimately cannot influence politics. ${ }^{53}$ Their disengagement is thus more related to the way in which politics is organized than due to their lack of interest. Looking to British qualitative studies we see highly similar opinions among adults, ${ }^{54}$ which forces us to consider that such misgivings about the political process and political participation may not be exclusive to young people.

In addition, survey results often portray youth political participation quite negatively. The validity of this observation, however, depends on the reference group of choice in that the results of comparing youth to adults or to the retired inevitably vary. ${ }^{55}$ Moreover, it is difficult to make comparisons between young people because most youth surveys focus on 12-18 year olds, while adult surveys often encompass those aged 18 and over. Thus when researchers wish to compare younger youth from the former category to those slightly older in the latter, they are forced to rely on data originating from different questionnaires, which complicates the task and potentially diminishes the accuracy of their claims. Moreover, certain studies of the adult population neglect the fact that some 18 year olds included in the surveys were ineligible voters in previous elections and so results from these surveys are accordingly skewed. Because some of those young people were not yet eligible to vote, the level of political participation will be lower, not because those young people do not want to vote but because they could not vote. Parry et al. ${ }^{56}$ maintain that such an oversight is ultimately insignificant as only half of the British population vote in elections anyway, but also because voting can be considered the least demanding form of political participation and so cannot be considered a prime indicator of political activity. Furthermore, Kavadias et al. ${ }^{57}$ compared the political attitudes of young people and of adults and concluded that neither group differed very much with respect to their attitudes or interest in politics. The inconsistency between declining levels of political participation and relatively higher levels of political interest in both youth and older people requires further investigation, according to $\mathrm{O}^{\prime}$ Toole. ${ }^{58}$ 
A closer study of the literature demonstrates that younger and older people display similar levels of political participation. ${ }^{59}$ Pattie et al., ${ }^{60}$ for instance, compared the attitudes of younger and older people and concluded that young people were less trusting than older people. So, in comparison to the older generation we would expect that young people carry a more negative attitude towards politics, while exhibiting less interest and less trust in the political process (hypothesis 3).

\section{Data and methods}

These three hypotheses will be tested using a secondary analysis of the Comparative Youth Survey (CYS 2006) and the European Social Survey (ESS). The CYS 2006 is a representative survey conducted in 2006 from among more than 6,000 15 and 16 year olds in Belgium (both in the French and Dutch communities), and 3,000 16-year-old Canadians ${ }^{61}$ (also within both the French and English communities). This study is based on written surveys filled out by the respondents in their schools. The survey focused on the social and political attitudes of young people. Political participation was questioned in two ways: participation during the last year, and future participation. We will use the last-year participation because data from the future participation category is considered less reliable. ${ }^{62}$ Nonetheless, there is little difference between the levels of political participation in either category.

The ESS was funded by the European Commission, the European Science Foundation and the National Science Foundations from 24 European countries (www.europeansocialsurvey.org). The study focuses on changes in social attitudes, values and behavioural patterns. The questionnaire includes two main sections, each consisting of approximately 120 items. The ESS aims to monitor change and continuity in a wide range of social variables, including media use; social and public trust; political interest and participation; socio-political orientations, governance and efficacy; moral, political and social values; social exclusion; national, ethnic and religious allegiances; well-being, health and security; demographics and socio-economics. In this analysis we will use mainly this part of the survey.

We will test our hypotheses using secondary analysis of the CYS 2006 and the ESS 2004 (round 2). We operationalize lifecycle effects by marital status, home ownership, completion of studies, employment and voting eligibility, all factors which enable the separation of youth and adults. For these analyses we will use the ESS. Examples of new and other forms of political participation used in the study include: the wearing of badges, the signing of petitions, legal demonstrations, as well as boycotting. Here, we will compare the ESS and the CYS 2006 data. We will use contacting and being a member of a political party as more traditional forms of participation. We will test the 'different attitudes' by comparing the levels of trust and interest among young and old people, both from the ESS and the CYS 2006.

\section{Hypotheses}

Now we will look to the empirical tests of the theory. We have three hypotheses:

H1: Differences between young and old in electoral behaviour and political participation can be attributed mainly to lifecycle effects. 
$\mathrm{H} 2$ : Young people prefer other forms of political participation than older people.

H3: Young people have different attitudes towards politics than older people.

\section{Results}

\section{Lifecycle effects tend to influence electoral behaviour and political participation}

Young people are certainly aware of these lifecycle effects. They know that they are not yet adults, but they expect that with age they will become influential. The last question in the CYS was open-ended: 'how can young people exert influence in society?' We found out that many young people think they will only have more influence when they get older, obtain a diploma, or become richer:

Not as a young person, older people will dominate us directly if we try to have an influence on society. (Male, age 15)

As a youngster [I think] you can't exert much influence, it will get better when you grow older. (Female, age 15)

To obtain a diploma and earn a lot of money. (Male, age 15)

Study first, then you will become influential. (Male, age 15)

Adolescents are very cynical about the possibility that they will ever acquire social influence: 'you need to be a millionaire, then they can squeeze money out of you' (Female, age 15). In the citizenship literature, we find a similar conclusion: young people are 'not-good-enough citizens and citizens of tomorrow, but not today', 'citizens-in-the-making' or 'future citizens'. ${ }^{63}$ That young people are largely unemployed furthermore diminishes the conception of them as fully fledged citizens.

Unfortunately, we only have 16-year-old respondents in the CYS 2006, so we cannot measure for generational effects. But we can easily use the ESS data to show how levels of political participation evolve throughout one's lifetime. We ask six questions: whether they have contacted a politician or government official, worked in a political party, worn or displayed a campaign badge or sticker, signed a petition, taken part in a lawful public demonstration, or boycotted a certain product in the last 12 months. We do not ask the participant whether they voted in the last election, because, as we have seen in theory, this question can be problematic for young people. Only $1 \%$ was active in five or six activities. On the other hand, $60 \%$ of the adult population undertook no activity: so, in general, adults (also) have low levels of political participation.

We divided our population into ten approximately equal groups according to age, as displayed in Figure 1. For each age group we reported the mean number of activities they engaged in within the last year. The question was whether young people participate less in politics, but, as we can see, they are neither the most active nor the laziest of the groups. Those aged $12-18$ on average participate in 0.6 activities, while the $19-25$ year olds engage in 0.7 activities. This pales in comparison to the results for those aged 60 and over who generally have more time for political action. According to the graph, however, when young people reach 26 years of age their political participation rates go up: this is no coincidence, as it 
Table 1. Percentage of the Adult People Engaged in Political Participation in the Last Year

\begin{tabular}{lc}
\hline $\begin{array}{l}\text { Number of } \\
\text { activities }\end{array}$ & $\begin{array}{c}\text { Percentage of } \\
\text { population }\end{array}$ \\
\hline 0 & 60.4 \\
1 & 21.2 \\
2 & 10.5 \\
3 & 4.9 \\
4 & 2.0 \\
5 & 0.8 \\
6 & 0.2 \\
\hline
\end{tabular}

Notes: Entries represent the percentage of people who engaged in a number of the following activities: made contact, worked in a political party, wore or displayed a campaign badge or sticker, signed a petition, demonstrated or boycotted a certain product in the previous 12 months.

Source: ESS data $(n=45,681)$.

roughly marks the age when young people settle and start planning for their own home and children. So, in general we can say that there is a lifecycle effect for political participation: as people grow older (up until their fifties) they become more active. But once passed their fifties, people again become less active.

But we can also take the lifecycle effects into account: not only age, but also if they are married, are homeowners, have finished their studies and what specific level of education they may have attained. Firstly, we will measure the impact of the lifecycle effects on voting. We will determine whether people were eligible to vote, and, if they were eligible, whether they have voted. It is important to determine whether the respondents were eligible voters because this is the only way to take young people into account. The independent variables are categorical variables: being married, being a homeowner, and the completion of studies, are all dichotomous variables $(0=$ no; $1=$ yes $)$. The level of education is a 7 -item scale

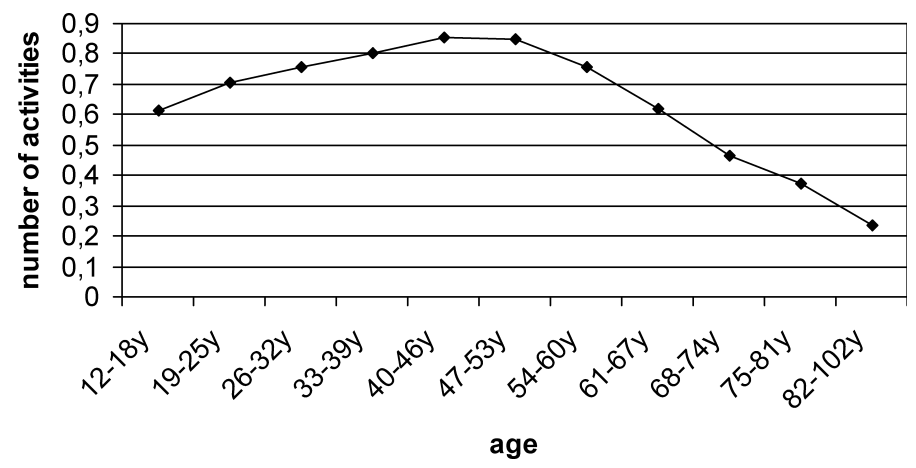

Figure 1. Mean number of activities by age. Entries represent the percentage of people who engaged in a number of the following activities: made contact, worked in a political party, wore or displayed a campaign badge/sticker, signed a petition, demonstrated or boycotted a certain product in the previous 12 months. Source: ESS data $(n=45,681)$. 
Table 2. Model for Lifecycle Effects on Voting

\begin{tabular}{lccc}
\hline & $\begin{array}{c}\text { Lifecycle } \\
\text { effects }\end{array}$ & $\begin{array}{c}\text { Lifecycle effects } \\
\text { with age }\end{array}$ & $\begin{array}{c}\text { Lifecycle effects } \\
\text { with age and } \\
\text { education }\end{array}$ \\
\hline $\begin{array}{l}\text { Being married } \\
\begin{array}{l}\text { Home owned by a member } \\
\text { of the family }\end{array}\end{array}$ & $0.085^{* * *}$ & $0.071^{* * *}$ & $0.062^{* * *}$ \\
$\begin{array}{l}\text { Finished studies } \\
\text { Ever worked }\end{array}$ & $0.092^{* * *}$ & $0.078^{* * *}$ & $0.075^{* * *}$ \\
$\begin{array}{l}\text { Age } \\
\text { Level of education }\end{array}$ & $0.132^{* * *}$ & $0.219^{* * *}$ & $0.199^{* * *}$ \\
$\begin{array}{l}\text { Number of cases } \\
\text { Adjusted } R^{2}\end{array}$ & & $0.136^{* * *}$ & $0.122^{* * *}$ \\
& 44,282 & $0.186^{* * *}$ & $0.205^{* * *}$ \\
& 0.199 & 44,102 & $0.129^{* * *}$ \\
& & 0.226 & 40,345 \\
\hline
\end{tabular}

Notes: Dependent variable: trichotomy—voting (not eligible to vote, no, yes). Ordinary least squares regression analysis. Main entries are standardized beta coefficients; ${ }^{*} p<0.05$; ${ }^{* *} p<0.01 ;{ }^{* * *} p<0.001$.

Source: ESS data.

(did not complete primary education, primary education, lower secondary, upper secondary, post-secondary/non-tertiary, first stage of tertiary, second stage of tertiary). Age is a continuous variable (from 12 to 102). The results in Table 2 indicate that being married, a member of a family, a homeowner, the completion of studies, and work experience all have a positive influence on voting. Also, being older has a positive effect on voting. The major explanation, however, is the level of education: people with higher education are more engaged in political participation. This is not surprising; educational attainment is often cited as the best predictor of voting and political participation. ${ }^{64}$ However, low levels of education are present among the older generation as well as the young, and, as we see in Figure 1, both of these groups tend to participate less.

Further, we can also try to fit the model for political participation. Here we also take into account whether respondents were eligible to vote in the model as we have seen that being eligible to vote leads to other forms of political participation. Being eligible to vote is also a dichotomous variable $(0=$ no; $1=$ yes $)$. We see that some lifecycle effects, though significant previously, are no longer consequential: i.e. being married has no influence on general political participation. Home ownership has a negative effect, but this can be explained by the fact that the ESS question relating to home ownership could be answered by anyone within the family, so younger respondents also replied 'yes' to the question. Having finished studies also has a slightly negative effect on political participation. But people with work experience are more inclined to participate. From this we can infer that the working environment can be a good agent of political socialization. ${ }^{65}$ In addition, voting eligibility in the previous election carries a positive influence on political participation: political participation seems to be highly cumulative. More unexpectedly, age is seen to have a negative effect on political participation. This might be because we do not take voting into account (which is most exercised by older people), and, as we have seen in Figure 1, older people tend to participate less in other, more alternative forms of political participation. Higher education also has a very large influence on 
Table 3. Model for Lifecycle Effects on Political Participation

\begin{tabular}{lccc}
\hline & $\begin{array}{c}\text { Lifecycle } \\
\text { effects }\end{array}$ & $\begin{array}{c}\text { Lifecycle effects } \\
\text { with age }\end{array}$ & $\begin{array}{c}\text { Lifecycle effects } \\
\text { with age and } \\
\text { education }\end{array}$ \\
\hline $\begin{array}{l}\text { Being married } \\
\text { Home owned by a member } \\
\text { of the family }\end{array}$ & -0.002 & 0.005 & -0.005 \\
$\begin{array}{l}\text { Finished studies } \\
\text { Ever worked }\end{array}$ & $-0.017^{* * *}$ & $-0.011^{*}$ & $-0.016^{* * *}$ \\
$\begin{array}{l}\text { Eligible to vote } \\
\text { Age }\end{array}$ & $0.109^{* * *}$ & $-0.052^{* * *}$ & $-0.071^{* * *}$ \\
Level of education & $0.022^{* * *}$ & $0.102^{* * *}$ & $0.071^{* * *}$ \\
Number of cases & & $0.036^{* * *}$ & $0.013^{*}$ \\
Adjusted $R^{2}$ & 44,282 & $-0.093^{* * *}$ & $-0.039^{* * *}$ \\
& 0.008 & 44,102 & $0.214^{* * *}$ \\
& & 0.015 & 0.0545 \\
\hline
\end{tabular}

Notes: Dependent variable: political participation (six forms of political participation: contact, member of political party, wear a badge/sticker, sign a petition, lawful demonstration, and boycotting). Cronbach's alpha: 0.56. Ordinary least squares regression analysis. Main entries are standardized beta coefficients; ${ }^{*} p<0.05$; ${ }^{* *} p<0.01$; ${ }^{* * *} p<0.001$.

Source: ESS data.

political participation. However, the explained variance of this model is substantially smaller than that of the previous model.

And so, it seems that Kimberlee's ${ }^{66}$ fear that lifecycle effects are not 'adequate to account for the low levels of electoral participation' is not altogether justified: $23 \%$ of the variation in voting can be explained by these lifecycle effects, while most variance can be explained through age and education. The model for all forms of political participation explains less variance because younger people prefer alternative forms of political participation. In general, we argue that the level of voting is more influenced by lifecycle effects than it is by levels of political participation.

\section{Young people prefer other forms of political participation than older people}

Young people do not always use the same forms of political participation as older people. They go beyond convention and find new ways to express their opinions. Moreover, this need to innovate is at least in part encouraged by their restricted voting rights. If we ask young people how they think they can exert influence in society, we find the following to be among the more traditional forms of participation: to be a good citizen, to be a member of an organization, to contact people, to protest, but also to wear 'alternative' clothes (punk, gothic, etc.), or through more aggressive forms of participation such as theft, drugs, etc. Nonetheless, most young people answer that they are unable to exert any influence at all.

The ESS includes only conventional forms of political participation. However, it does incorporate boycotting, the signing of petitions, as well as demonstrations. New forms of participation are indeed very popular among young people; here, badge-wearing and demonstrating are the most practised. Signing a petition is a typical activity for people younger than 60. Boycotting a product and contacting a politician are most frequently practised by $40-60$ year olds. Political party membership is most common among older people. More than one-third of the members 
Table 4. Differences in Political Participation Between Different Age Groups

\begin{tabular}{|c|c|c|c|c|c|}
\hline & \multicolumn{2}{|c|}{ CYS 2006} & \multicolumn{3}{|c|}{ ESS } \\
\hline & Canada & Belgium & $\begin{array}{c}\text { Young } \\
\text { (12-40 years) }\end{array}$ & $\begin{array}{c}\text { Medium } \\
\text { (41-60 years) }\end{array}$ & $\begin{array}{c}\text { Old } \\
\text { (61-102 years) }\end{array}$ \\
\hline$\%$ contacted & n.a. & 4.4 & 12.6 & 18.5 & 11.9 \\
\hline $\begin{array}{l}\% \text { member of } \\
\text { political party }\end{array}$ & 2.2 & 0.8 & 3.2 & 6.2 & 7.3 \\
\hline$\%$ wore badge & 33.3 & 15.4 & 8.9 & 8.1 & 4.8 \\
\hline$\%$ signed petition & 52.0 & 39.8 & 24.4 & 24.3 & 13.8 \\
\hline $\begin{array}{l}\text { \% demonstrated } \\
\text { legally }\end{array}$ & 21.7 & 11.5 & 9.5 & 8.0 & 3.6 \\
\hline$\%$ boycotted & 27.2 & 18.4 & 15.2 & 17.2 & 10.2 \\
\hline Number of cases & 3,334 & 6,330 & 18,563 & 15,337 & 11,517 \\
\hline
\end{tabular}

Notes: Entries represent the percentage of people in that age group who engaged in the particular activity in the previous year.

${ }^{\mathrm{a}}$ The Belgian and Canadian surveys also asked about the wearing of a T-shirt.

n.a.: The Canadian survey did not ask about making contact.

Source: CYS 2006; ESS data.

of political parties in Europe are older than $60 .{ }^{67}$ Not surprisingly, the predominance of the older generation in political party membership makes it more difficult for young people to join, even while it deters them from participating in politics. It is interesting to note that young Canadians are somewhat more inclined to participate. To conclude, it is clear from our analyses that young people indeed prefer different forms of political participation than those undertaken by older people.

Young people have different attitudes towards politics than older people

Young people certainly believe they are not heard in the political sphere: more than $75 \%$ of young people feel that politicians do not represent them in the way

Table 5. Attitudes Towards Political Parties (Canadian and Belgian Respondents)

\begin{tabular}{lcccc}
\hline & $\begin{array}{c}\text { Disagree } \\
\text { strongly }\end{array}$ & $\begin{array}{c}\text { Disagree } \\
\text { somewhat }\end{array}$ & $\begin{array}{c}\text { Agree } \\
\text { somewhat }\end{array}$ & $\begin{array}{c}\text { Agree } \\
\text { strongly }\end{array}$ \\
\hline $\begin{array}{c}\text { Political parties and parliament } \\
\text { have too much power compared } \\
\text { to citizens }\end{array}$ & 4.7 & 21.5 & 50.6 & 23.3 \\
$\begin{array}{c}\text { Political parties truly represent the } \\
\text { interests of young people like me }\end{array}$ & 31.9 & 46.9 & 18.6 & 2.6 \\
$\begin{array}{c}\text { Political parties are only interested in } \\
\text { people's votes, not in their opinions }\end{array}$ & 6.1 & 22.3 & 44.7 & 26.9 \\
$\begin{array}{l}\text { In a democracy, some people simply } \\
\text { know more about political issues, } \\
\text { so they should have more influence } \\
\text { on these matters }\end{array}$ & 11.6 & 32.9 & 48.9 & 6.6 \\
\hline
\end{tabular}

Notes: Number of cases: 6,330 +3,334. Entries represent the percentage of respondents who answered the statements.

Source: CYS 2006. 
Table 6. Mean Score on Trust in Institutions

\begin{tabular}{|c|c|c|c|c|}
\hline & \multicolumn{2}{|c|}{ CYS 2006} & \multirow[b]{2}{*}{ ESS } & \multirow{2}{*}{$\begin{array}{c}T \text {-test } \\
\text { significance }\end{array}$} \\
\hline & Belgium & Canada & & \\
\hline Trust in country's parliament ${ }^{a}$ & $4.70(2.42)$ & $4.96(2.52)$ & $4.52(2.47)$ & $-5.4^{* * *}$ \\
\hline Trust in the legal system ${ }^{b}$ & $5.44(2.52)$ & $6.08(2.31)$ & $5.07(2.61)$ & $-10.7^{* * *}$ \\
\hline Trust in the police & $5.05(2.62)$ & $6.11(2.53)$ & $5.87(2.59)$ & $23.3^{* * *}$ \\
\hline Trust in political parties & $4.03(2.43)$ & n.a. & $3.66(2.30)$ & $-11.1^{* * *}$ \\
\hline $\begin{array}{l}\text { Trust in the European } \\
\text { Parliament }\end{array}$ & $5.37(2.56)$ & n.a. & $4.57(2.41)$ & $-22.8^{* * *}$ \\
\hline Number of cases & 6,330 & 3,334 & 45,681 & \\
\hline
\end{tabular}

Notes: Entries represent the mean scores for trust in people. Standard deviations are shown in parentheses. $T$-test: $t$-value and ${ }^{*} p<0.05 ;{ }^{* *} p<0.01 ;{ }^{* * *} p<0.001$; comparing Belgian and ESS data.

${ }^{\mathrm{a} C}$ CYS 2006 asked about trust in the Belgian/Canadian parliament.

${ }^{\mathrm{b} C Y S} 2006$ asked about trust in courts.

Source: ESS data; CYS 2006 data.

they want and do not know what their interests are. However, this difference is greater among Canadians. They also find that they do not have enough to say in politics, and that politicians are not interested in people's opinions, only in their votes.

A significant body of research states that young people have a negative view of politics that is characterized by low levels of political participation, political interest and trust. Comparing the data of the CYS 2006 with those of the ESS (see Table 6), we find that while young people have low levels of trust, they are by no means lower than those displayed by the adult population (both on a 10-item scale). Only with respect to trusting the police do Belgian youth score lower than Belgian adults. Thus, even though young people indeed have low levels of trust these do not differ significantly from adult levels of trust. We can draw similar conclusions in relation to political interest: young people have a mean score of 2.02, which means that they are 'quite interested'; the adult population scores 2.63, which means they score between 'quite' and 'hardly interested' (both on a 4-item scale). Both young people and adults not only have similar levels of trust but also share similar levels of political interest.

\section{Conclusion}

A review of the quantitative analysis demonstrates that the way young people feel about politics is in fact similar to what the theory describes. As stated in the literature, though lifecycle effects account for many of the differences in voter turnout, they can only explain minor differences in political participation. Larger differences in political participation are explained by the level of educational attainment. Secondly, young people really do engage in other, newer forms of participation, which include wearing badges, signing petitions and demonstrating. Although this is only a small sample, even here we find differences between young and old. Thirdly, young people certainly feel unheard. We have already shown that young people do not differ much with respect to their 
levels of political participation when compared to older people, especially when other factors are taken into account. Similarly, young people and old people display comparable levels of trust in political institutions and political interest. Accordingly, the following should be added to the literature: young people are not more negative than adults in their political attitudes, and this is true for both political trust and political interest.

Young people are less likely to participate in political activities because they do not feel attracted to politics. Their indifference in the matter is influenced by lifecycle effects such as housing, marriage, employment, and so on, which they generally do not yet have. Young people operate with a very narrow conception of politics that is restricted to formal politics only. Such a limited definition inevitably makes politics appear altogether irrelevant in their lives. And while international politics may in fact be less relevant, educational and leisure politics do affect young people directly. Accordingly, the scope of civic education should be widened beyond a simple transfer of knowledge and play a necessary role in conveying the importance and value of politics. Political indifference is not specific to young people, however, as contemporary research points to similar attitudes among adults: ${ }^{68}$ they have little political knowledge, are barely interested, are not engaged, lack confidence, trust and efficacy, and so on. Ultimately, it seems that young people and adults are not so different in their political attitudes, with the exception that young people have fewer opportunities to participate politically.

Zukin et al. ${ }^{69}$ cite many possible reasons to account for low levels of political participation among young people before concluding that there is no single overwhelming deterrent. While no switch exists to instantly activate political participation on the part of youth there are some macro and micro dimensions that could be developed. Changes in voter registration and electoral systems (compulsory voting, lowering the age of voting), the enhancement of civic education programmes in schools, and the promotion of alternative forms of participation could all help to stimulate greater political action among youth.

\section{Notes}

1. Attributed to Socrates by Plato, according to William L. Patty and Louise S. Johnson, Personality and Adjustment, New York, 1953, p. 277.

2. S. Keeter et al., 'Three Core Measures of Community-based Civic Engagement: Evidence from the Youth Civic Engagement Indicators Project', Paper presented at the Child Trends Conference on Indicators of Positive Development, Washington, DC, 11-12 March 2003; T. O'Toole et al., 'Tuning Out or Left Out? Participation and Nonparticipation among Young People', Contemporary Politics, Vol. 9, No. 1, 2003, pp. 45-61.

3. M. Gauthier, 'The Inadequacy of Concepts: The Rise of Youth Interest in Civic Participation in Quebec', Journal of Youth Studies, Vol. 6, No. 3, 2003, pp. 265-76; R. H. Kimberlee, 'Why Don't British Young People Vote at General Elections?', Journal of Youth Studies, Vol. 5, No. 1, 2002, pp. 85-98; K. Dolan, 'Attitudes, Behaviors, and the Influence of the Family: A Reexamination of the Role of Family Structure', Political Behavior, Vol. 17, No. 3, 1990, pp. 251-64.

4. M. Hooghe, D. Stolle and P. Stouthuysen, 'Head Start in Politics: The Recruitment Function of Youth Organizations of Political Parties in Belgium (Flanders)', Party Politics, Vol. 10, No. 2, 2004, pp. 193-212.

5. O'Toole et al., op. cit., pp. 45-61; M. Henn, M. Weinstein and S. Forrest, 'Uninterested Youth? Young People's Attitudes towards Party Politics in Britain', Political Studies, Vol. 33, 2003, pp. 556-78. 
6. K. Eden and D. Roker, Youth and Social Action, Leicester, 2002. O'Toole et al., op. cit., pp. 45-61, at pp. 50-1; D. Wring, M. Henn and M. Weinstein, 'Committed Scepticism or Engaged Cynicism? Young People and Contemporary Politics', in J. Fisher et al. (eds), British Parties and Elections Review, 9, London, 1999, pp. 200-16; D. Roker, K. Player and J. Coleman, Challenging the Image: Young People as Volunteers and Campaigners, Leicester, 1999, p. 186; A. Russell et al., Voter Engagement and Young People, London, 2002, pp. $14-17$.

7. Kimberlee, op. cit., pp. 85-98.

8. B. Highton and R. E. Wolfinger, 'The First Seven Years of the Political Life Cycle', American Journal of Political Science, Vol. 45, No. 1, 2001, pp. 202-9.

9. S. M. Lipset, Political Man: The Social Bases of Politics, New York, 1963 [1960]; N. H. Nie, S. Verba and J. Kim, 'Political Participation and the Life Cycle', Comparative Politics, Vol. 6, No. 3, 1974, pp. 319-40; R. E. Wolfinger and J. R. Steven, Who Votes?, New Haven, 1980.

10. P. Martikainen, T. Martikainen and H. Wass, 'The Effect of Socioeconomic Factors on Voter Turnout in Finland: A Register-based Study of 2.9 million Voters', European Journal of Political Research, Vol. 44, No. 5, 2005, pp. 645-69.

11. C. Zukin et al., A New Engagement? Political Participation, Civic Life, and the Changing American Citizen, New York, 2006.

12. Highton and Wolfinger, op. cit., pp. 202-9; N. Babchuk and A. Booth, 'Voluntary Association Membership: A Longitudinal Analysis', American Sociological Review, Vol. 34, No. 1, 1969, pp. 31-45.

13. L. Stoker and M. K. Jennings, 'Life-cycle Transitions and Political Participation: The Case of Marriage', American Political Science Review, Vol. 89, 1995, pp. 421-34; N. Burns, K. L. Schlozman and S. Verba, The Private Roots of Public Action: Gender, Equality, and Political Participation, Cambridge, MA, 2001.

14. P. Norris, 'Young People and Political Activism: From the Politics of Loyalties to the Politics of Choice?', Paper presented at the 'Civic Engagement in the 21st Century: Toward a Scholarly and Practical Agenda' conference at the University of Southern Carolina, 1-2 October 2004.

15. S. Keeter et al., op. cit.; IDEA, The International IDEA Database: Voter Turnout from 1945 to 2001，2002，<http://www.idea.int/publications/vt/upload/IDEA\%20database.pdf>, accessed 10 January 2007.

16. D. Owen, 'Dilemmas and Opportunities for the Young Active Citizen', Youth Studies Australia, Vol. 15, No. 1, 1996, pp. 20-4.

17. G. Parry, G. Moyser and N. Day, Political Participation and Democracy in Britain, Cambridge, 1992.

18. J. Bessant, 'Mixed Messages: Youth Participation and Democratic Practice', Australian Journal of Political Science, Vol. 39, No. 2, 2004, pp. 387-404; Eden and Roker, op. cit.

19. Zukin et al., op. cit.; it could be argued that they might have the same chances, but certainly not the same opportunities (money, transport, permission, etc.).

20. Ibid.; M. K. Jennings and R. G. Niemi, Generations and Politics: A Panel Study of Young Adults and their Parents, Princeton; Kimberlee, op. cit., pp. 85-98; R. D. Putnam, Bowling Alone: The Collapse and Revival of American Community, New York.

21. Russell et al., op. cit.

22. Kimberlee, op. cit., pp. 85-98; Putnam, op. cit.; Zukin, op. cit.

23. Martikainen et al., op. cit., pp. 645-69.

24. J. J. Arnett, 'The Psychology of Globalization', American Psychologist, Vol. 57, No. 10, 2002, pp. 774-83; O'Toole et al., op. cit., pp. 45-61.

25. O'Toole et al., op. cit., pp. 45-61; B. Hoskins, 'What about Political Participation?', Research seminar, European Youth Centre, Strasbourg, 24-26 November 2003.

26. O'Toole et al., op. cit., pp. 50-1.

27. R. Wuthnow, Loose Connections: Joining Together in America's Fragmented Communities, Cambridge, MA, 1998.

28. L. Edwards, Politics not Parties: Young People and Political Engagement. Findings from a Series of Discussion Groups with Young People, London, 2001.

29. P. Norris, 'Political Activism: New Challenges, New Opportunities', in C. Boix and S. Stokes (eds), Oxford Handbook of Comparative Politics, Oxford, 2005; D. Roker, K. Player and J. Coleman, 'Young People's Voluntary Campaigning Activities as 
Sources of Political Education', Oxford Review of Education, Vol. 25, No. 1/2, 1999, pp. 185-98.

30. Hoskins, op. cit.

31. Eden and Roker, op. cit.; R. J. Dalton, Citizen Politics in Western Democracies: Public Opinion and Political Parties in the United States, Great Britain, West Germany, and France, New York, 1988; Gauthier, op. cit., pp. 265-76; M. Kaase, 'Social Movements and Political Innovation', in R. Dalton and M. Kuechler (eds), Changing the Political Order: New Social Movements in Western Democracy, Oxford, 1990; M. Micheletti, A. Follesdal and D. Stolle, Politics, Products, and Markets: Exploring Political Consumerism Past and Present, New York, 2003; T. O'Toole, 'Explaining Young People's Nonparticipation: Towards a Fuller Understanding of the Political', Paper presented at the European Consortium for Political Research Joint Sessions of Workshops, University of Uppsala, 2004; Roker et al., 'Young People's Voluntary Campaigning Activities as Sources of Political Education', op. cit., pp. 185-98; S. Barnes and M. Kaase (eds), Political Action: Mass Participation in Five Western Democracies, Beverly Hills, 1979; C. Hay, Why We Hate Politics, Cambridge, 2007; D. Marsh, T. O'Toole and S. Jones, Young People and Politics in the UK: Apathy or Alienation?, Basingstoke, 2006.

32. M. Henn, M. Weinstein and D. Wring, 'A Generation Apart? Youth and Political Participation in Britain', British Journal of Politics and International Relations, Vol. 4, No. 2, 2002, pp. 167-92.

33. Ibid.

34. Zukin, op. cit.

35. K. Bhavnani, Talking Politics: A Psychological Framing of Views from Youth in Britain, Cambridge, 1994; J. Bynner and S. Ashford, 'Politics and Participation: Some Antecedents of Young People's Attitudes to the Political System and Political Activity', European Journal of Social Psychology, Vol. 24, No. 2, 1994, pp. 223-36.

36. There are also tendencies for adults to use a narrow conception of politics; C. Flanagan and L. S. Gallay, 'Reframing the Meaning of "Political" in Research with Adolescents', Perspectives on Political Science, Vol. 24, No. 1, 1995, pp. 34-42.

37. Hay, op. cit., pp. 61-2.

38. Parry et al., op. cit.

39. Bynner and Ashford, op. cit., pp. 223-36.

40. Henn et al., 'Uninterested Youth?', op. cit., pp. 556-78; Hay, op. cit.

41. Roker et al., Challenging the Image, op. cit.

42. Keeter et al., op. cit.

43. Henn et al., 'Uninterested Youth?', op. cit., pp. 556-78; V. J. Furlong and F. Cartmel, Young People and Social Change-Individualization and Risk in Late Modernity, Milton Keynes, 1997.

44. O'Toole et al., op. cit., pp. 45-61.

45. Keeter et al., op. cit.

46. O'Toole et al., op. cit., pp. 45-61.

47. Nie et al., 'Political Participation and the Life Cycle', op. cit., pp. 319-40; S. Iyengar and S. Jackman, 'Technology and Politics: Incentives for Youth Participation', CIRCLE Working Paper No. 24, Center for Information and Research on Civic Learning and Engagement, College Park, MD, 2004.

48. Henn et al., 'A Generation Apart?', op. cit., pp. 167-92.

49. Bessant, op. cit., pp. 387-404.

50. O'Toole, op. cit.

51. Henn et al., 'A Generation Apart?', op. cit., pp. 167-92.

52. O'Toole et al., op. cit., pp. 45-61; Kimberlee, op. cit., pp. 85-98.

53. Henn et al., 'A Generation Apart?', op. cit., pp. 167-92; Kimberlee, op. cit., pp. 85-98.

54. C. Pattie, P. Seyd and P. Whiteley, Citizenship in Britain: Values, Participation and Democracy, Cambridge, 2004; V. Ram, 'Public Attitudes to Politics, Politicians and Parliament', Parliamentary Affairs, Vol. 59, No. 1, 2006, pp. 188-97.

55. A. Russell, 'The Truth about Youth? Media Portrayals of Young People and Politics in Britain', Journal of Public Affairs, Vol. 4, No. 4, 2004, pp. 347-54.

56. Parry et al., op. cit. 
57. D. Kavadias, J. Siongers and F. Stevens, 'Jongeren en politiek in de jaren ' 90 ', Working Paper 10, Vakgroep Sociologie, Onderzoeksgroep TOR, Vrije Universiteit Brussel, 1999.

58. O'Toole, op. cit.

59. D. Kavadias, De houdingen van adolescente Vlamingen aan de dageraad van de $21^{\text {ste }}$ eeuw. Een overzicht, Onuitgegeven onderzoeksrapport, Brussel, vakgroep Sociologie, 2001; Kavadias et al., op. cit.; J. Siongers and W. Smits, 'Jongeren en politiek. Maatschappelijke betrokkenheid is een werkwoord', TGL Spiritualiteit, Vol. 61, No. 1, 2005, pp. 51-64; A. Furnham and B. Gunter, The Anatomy of Adolescence: Young People's Social Attitudes in Britain, London, 1989.

60. Pattie et al., op. cit.

61. However, we compare the Canadian data with the ESS and maintain that this comparison has value. In Canada, we already have similar research (Gauthier, op. cit., 2003). Canada is also a Western country with different political parties (where the USA, have only two major parties). Another advantage is that Canada conducted the same questions at the same time among a similar group of people.

62. H. Brady, 'Political Participation', in J. P. Robinson, P. R. Shaver and L. Wrightsman (eds), Measures of Political Attitudes, San Diego, 1999, pp. 737-801; Norris, 'Young People and Political Activism', op. cit.; K. Uba, 'Measuring and Studying Political Participation-Different Methods, Problems, Solutions', Karlstad Seminar on Studying Political Action, 2005.

63. T. H. Marshall, Citizenship and Social Class and Other Essays, Cambridge, 1950; N. Smith et al., 'Young People as Real Citizens: Towards an Inclusionary Understanding of Citizenship', Journal of Youth Studies, Vol. 8, No. 4, 2005, pp. 425-43.

64. Norris, 'Young People and Political Activism', op. cit.; S. J. Rosenstone and J. M. Hansen, Mobilization, Participation, and Democracy in America, New York, 1993; L. W. Milbrath and M. L. Goel, Political Participation: How and Why Do People Get Involved in Politics?, Chicago, 1977; D. C. Mutz and J. J. Mondak, 'The Workplace as a Context for Crosscutting Political Discourse', Journal of Politics, Vol. 68, No. 1, 2006, pp. 140-55; N. H. Nie, J. Junn and K. Stehlik-Barry, Education and Democratic Citizenship, Chicago, 1996.

65. Mutz and Mondak, op. cit., pp. 140-55.

66. Kimberlee, op. cit., pp. 85-98.

67. R. J. Dalton and M. P. Wattenberg, Parties without Partisans: Political Change in Advanced Industrial Democracies, Oxford, 2000.

68. Pattie et al., op. cit.; Ram, op. cit., pp. 188-97.

69. Zukin, op. cit. 